\title{
Salar Energy
}

And Sustainable Development

Refereed, biannual scientific journal issued by

Center for Solar Energy Research and Studies

\section{Optimum Sizing of Residential Active Solar Water Heating Systems for Libyan Families}

\author{
M.J.R. Abdunnabi ${ }^{1}$, M. Al-Ahjal ${ }^{2}$, and Ibrahim O. Rahoma ${ }^{3}$ \\ ${ }^{1}$ Center for Solar Energy Research and Studies, Tripoli-Libya \\ ${ }^{2}$ Libyan Academy, School of Engineering and Applied Science, Mechanical Department, Tripoli-Libya \\ 3College of Engineering Technology. Janzour-Libya \\ e-mail: ${ }^{1}$ m_abdunnabi@csers.ly; ${ }^{2}$ milanetto2005@gmail.com; ${ }^{3}$ ibrahim_irhoma@yahoo.co.uk
}

Abstract: This paper investigates the optimum sizing of active solar water heaters for residential sector in Libya according to family size, typical weather condition and typical operating condition. An active solar water heating system model built in TRNSYS was used to evaluate the thermal performance of the system, while the optimization process was accomplished using genetic algorithm technique. Nine design parameters were chosen for the optimization, and their search space of the problem under investigation was defined. Three Libyan family sizes were suggested for the investigation for optimum solar water heaters; 4,6 , and 8 people. The Parito optimal front of the cost function for the three cases was plotted as function of system's solar fraction. The design parameters of some feasible non-dominated solutions are presented in tables. These results confirm the effectiveness of using the genetic algorithm technique for solar water heating system optimization

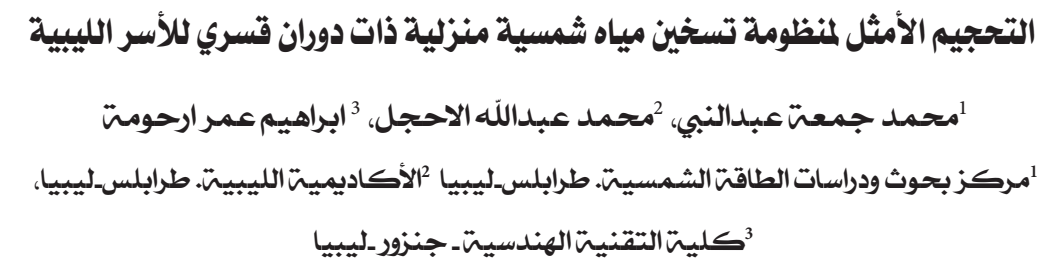

ملخص: تتفحص هذه الورقت الحجم الأمثل لمنظومت تسخين المياه الشمسيت المنزليت ذات الدوران القسري يِّ ليبيا طبقا لحجمى الأسـرة،

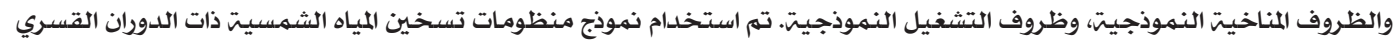

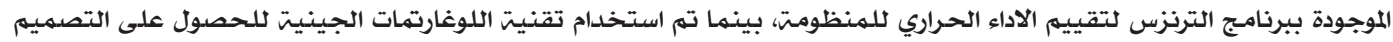

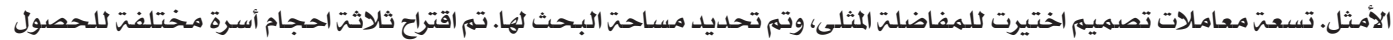

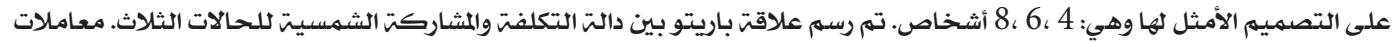

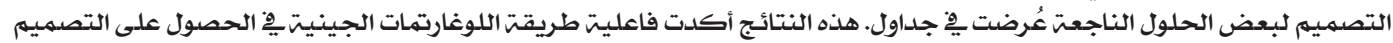
الأمثل للسخان الشمسي.

Keywords: active solar water heaters, optimization, TRNSYS simulation. 


\section{INTRODUCTION}

Hot water for domestic purposes represents $32 \%$ of the energy consumption of the residential sector in Libya. This form of energy (low temperature energy) can be efficiently provided with using solar water heating (SWH) technologies by means of active and passive solar water heaters. However, the cost of solar water heaters is still very high compared to other alternatives, and hence is not competitive.

Reducing the prices of solar water heating systems by developing the technology will highly contribute to the large scale dissemination of this technology. Well designed (SWH) systems are also required to reduce the cost of these systems and increase their efficiency.

Sizing of solar water heaters is not an easy job; however, it is very important to produce costeffective systems, as the cost is the main factor that affects the spread of this technology. Literature has revealed that there are no systematic easy-to-use methods for sizing and optimizing SWH systems, and that most systems available in the market were designed based on trial and error methods which are more based on intuition rather than scientific methods [1].

A great deal of work [2-12] has been published regarding sizing and optimizing of thermosyphon systems as well as active solar water heating systems [13-18] by using classical optimization techniques. However, only limited work has been devoted to the use of evolutionary algorithms to optimize large scale solar water heaters utilized in industrial or service applications.

Based on experimental and simulation analysis, Kicsiny and Farkas [13] have improved differential control unit, which operated with fixed switchon and switch-off temperature differences, and were compared in different efficiency viewpoints. The comparison was based on results of practical experiment and simulation program using TRNSYS. The results showed that the benefit of improved differential control reduces the run and stop of the pump.
Jason et al. [14] presented the optimal configuration of a combi-system in terms of life cycle energy and cost given the Canadian climate equipment, and energy costs. Additionally, the paper presented the effectiveness of certain optimization techniques when they were applied to solar combisystems. The transient simulation software TRNSYS was used with a model of an energy efficient house in Montreal that was equipped with a solar combisystem. A hybrid practical swarm and Hooke-Jeeves optimization algorithm was used to determine the optimal configuration of the solar combi-system. Two separate objective functions were used to find two separate optimal configurations in terms of life cycle cost and life cycle energy. The hybrid particle swarm optimization and Hooke-Jeeves algorithm was effective at reducing the value of the objective function regardless of which objective function was considered. The LCC of the combi-system was reduced by $16-19 \%$ and the LCE was reduced by $34 \%$ compared to the base case combi-system which was designed based on design recommendation to meet the needs of the house. Finally, a combi-system that performed well in terms of life cycle cost would perform poorly in terms of life cycle energy.

Krause, et al. [15] have used three different optimization procedures, which are expected to improve the performance of large solar thermal systems. The first procedure concerns the planning phase of the system. The second one considers its operation and should be carried out after about one year of data collection. The third one examines the daily performance considering predictions of weather and hot water consumption and the actual temperature level in the buffer store. For all three optimization steps the feasibility and the energetic potential have been investigated. For these studies validated system models of two solar domestic hot water systems in Germany have been implemented in TRNSYS. In combination with the simulations, both classical algorithms and Evolutionary Algorithms have been applied for the optimization procedures.

Chang and Minardi [16] A mathematical correlation between collector area and auxiliary 
energy used in a solar hot water system was obtained by using TRNSYS program. Based on the correlation, optimum collector area was directly related to both economic factors and system parameters. A criterion for economic feasibility was obtained. A comparison of optimum area calculated by this analysis with optimum area based on f-chart data was in good agreement,

Govind et al. [17] proposed a methodology to determine the design space for synthesis, analysis, and optimization of solar water heating systems. The proposed methodology includes various design constraints to determine all possible designs or a design space on a collector area vs. storage volume diagram. The design space is represented by tracing constant solar fraction lines on a collector area vs. storage volume diagram. It has been observed that there exists a minimum as well as a maximum storage volume for a given solar fraction and collector area. Similarly existence of a minimum and a maximum collector area is also observed for a fixed solar fraction and storage volume. For multiobjective optimization, a Pareto optimal region is also determined. Based on the identified design space, the solar water heating system is optimized by minimizing annual life cycle cost. Due to uncertainty in solar insolation, system parameters and cost data, global optimization may not be utilized to represent a meaningful design. To overcome this, a region of possible design configurations is also identified in the study.

Pereira et al. [18] presented a new method for the design and optimization of solar industrial process hot water systems with storage. The singlepass open-loop designed thermally "decouples" collectors from storage, hence insuring that collectors always heat the coldest fluid possible and that stored heat can be completely depleted by the nighttime load. So the single-pass openloop design, in spite of the relatively low flow rates entailed, operated at higher system efficiency than conventional system designs. One solved example for an industrial hot water application shows that the single-pass open-loop design delivered about 30 percent more useful energy with roughly
30 percent less storage than the conventional design. In addition, storage tanks did not have to stand high pressures and can thus be significantly cheaper than in conventional systems. The effects of collector operating time, heat exchangers, and secondary system losses are also treated. The new method was extended to cover systems that require weekend storage. The introduction of weekend storage might be cost effective because it enabled the designer to reduce collector area without reducing the yearly useful energy delivered by the system.

Brandemuehl et al [19] developed a procedure for assessing the economic viability of a solar heating system in terms of the life cycle savings of a solar heating system over a conventional heating system. The life cycle savings were expressed in a generalized form by introducing two economic parameters, $\mathrm{p} 1$ and $\mathrm{p} 2$, which relate all life cycle cost considerations to the first year fuel cost or the initial solar system investment cost. Using the generalized life cycle savings equation, a method was developed for calculating the solar heating system design which maximizes the life cycle savings. A similar method was developed for determining the set of economic conditions at which the optimal solar heating system design was just competitive with the conventional heating system. The results of these optimization methods could be presented in tabular or graphical form. The sensitivity of the economic evaluation and optimization calculations to uncertainties in constituent thermal and economic variables was also investigated.

In this paper, developing a design tool for sizing active solar water heaters using multi-objective optimization technique (genetic algorithm) and evaluating the performance of the system by using TRNSYS simulation program is presented.

\section{SWHS OPTIMISATION TOOL}

The design tool used in this study is based on TRNSYS simulation program to evaluate the thermal performance of forced circulation $\mathrm{SWH}$ systems as shown in Figure 1, and the genetic algorithm routine for the optimization. The optimization problem is defined as a multi-objective 
problem consisting of three objective functions: the cost of material contained or components in the system, the system performance (solar fraction in this case), and the average outlet temperature to the load. However, the problem can simply be treated as a constrained single optimization problem where the costs function is chosen as the objective and the other two objectives treated as constraints. The problem can then be stated as:

$$
\text { Minimise } \operatorname{Cost}(\overrightarrow{\mathrm{x}})
$$

Subject to:

$$
\begin{aligned}
& \mathrm{SF}(\overrightarrow{\mathrm{x}}) \geq \varepsilon_{1} \\
& \mathrm{~T}_{\text {use }}(\overrightarrow{\mathrm{x}}) \geq \varepsilon_{2}
\end{aligned}
$$

Where $\vec{x}=\left[x_{1}, x_{2}, \ldots, x_{n}\right]^{T}$ is the vector of the $n$ design variables of the system that are to be optimized and each variable $\mathrm{x}_{\mathrm{i}}$ is bounded by lower and upper limits $\left[\mathrm{x}_{1}^{\mathrm{L}}, \mathrm{x}_{\mathrm{i}}^{\mathrm{U}}\right] . \varepsilon_{1}$ and $\varepsilon_{2}$ are lower bounds of the constraints that can be varied to find multiple points on the Pareto-optimal front. The cost function is:

$$
\text { Cost }=A_{c} * C_{c}+V_{t} * C_{t}
$$

Where:

$$
\begin{aligned}
& \mathrm{A}_{\mathrm{C}} \text { : Collector area }\left(\mathrm{m}^{2}\right) \\
& \mathrm{V}_{\mathrm{t}}: \text { Tank volume }\left(\mathrm{m}^{3}\right) \\
& \mathrm{C}_{\mathrm{C}}: \text { Solar collector cost }\left(\mathrm{L} \cdot \mathrm{D} / \mathrm{m}^{2}\right) \\
& \mathrm{C}_{\mathrm{t}} \text { : Storage tank cost }\left(\mathrm{L} . \mathrm{D} / \mathrm{m}^{3}\right)
\end{aligned}
$$

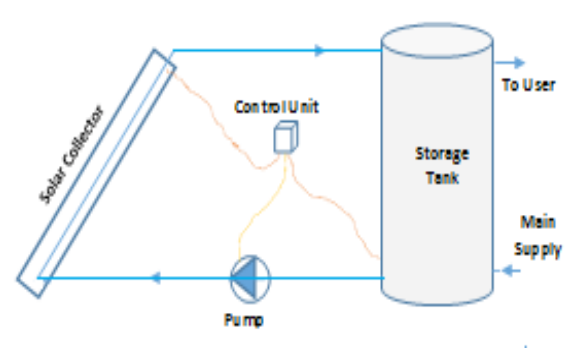

Figure (1). Forced circulation solar water heater

Nine parameters were chosen to determine the optimal characteristics of the forced circulation system. Each parameter is varied over a range of values chosen from literature and practical experience. The system design parameters considered for optimization are listed in Table 1.

\section{HOW IT WORKS}

The process starts by running the optimization program and this, in turn, creates an output file containing the values of the design variables of the SWH system in equation format (TRNSYS Equations). Once the output file is created, the optimization program calls TRNSYS to run the active SWH system project, using the output file as an input to the TRNSYS program. Using the 'include' statement at the beginning of the TRNSYS program allows the output files produced by the optimizer to be read and included in the TRNSYS program. The TRNSYS active SWH system project, in turn, produces an output file that contains the value of the system solar fraction and the value of the temperature to the load, which represents the values of the constraint in the optimizer. The output file produced by TRNSYS is then considered as an input file to the optimization program. This process is repeated for each candidate solution in all generations until the solution is found. This process is illustrated graphically in Figure 2.

\section{RESULTS AND DISCUSSION}

The design tool can be implemented to obtain the optimum SWH system to suit a variety of households, conditions and geographic locations. The design tool is applied according to the weather and operating conditions of Tripoli, Libya. The quantity of hot water per person per day is about 57 (taken 60 liters in this study) liters at withdrawal temperature of $45^{\circ} \mathrm{C}$. A typical hot water load pattern for Libyan families as depicted in Figure 3 was used [20]. The technical and thermal specifications of the main components of the system are shown in Table 2. 
Table (1). Design variables of SWH system

\begin{tabular}{|l|l|l|c|c|}
\hline & Abbr & Stand for & Limits & increment \\
\hline 1 & $\mathrm{Nc}$ & Number of collectors & {$[1,5]$} & 1 \\
\hline 2 & Ac & $\begin{array}{l}\text { Collectors cross } \\
\text { area }\left(\mathrm{m}^{2}\right)\end{array}$ & {$[1,2.2]$} & 0.05 \\
\hline 3 & $\beta$ & Collector tilt angle & {$[30,47]$} & 1 \\
\hline 4 & Mp & $\begin{array}{l}\text { Pump mass flow } \\
\text { rate }(\text { kg/hr })\end{array}$ & {$[100,800]$} & 20 \\
\hline 5 & DTx & $\begin{array}{l}\text { Maximum controller } \\
\text { Temperature }{ }^{\circ} \mathrm{C}\end{array}$ & {$[5,10]$} & 0.5 \\
\hline 6 & DTn & $\begin{array}{l}\text { Minimum controller } \\
\text { Temperature }{ }^{\circ} \mathrm{C}\end{array}$ & {$[1,4]$} & 0.25 \\
\hline 7 & Vt & Tank volume $\left(\mathrm{m}^{3}\right)$ & $\begin{array}{c}0.65^{\star} \mathrm{Vt} \\
1.3^{*} \mathrm{Vt}\end{array}$ & 0.005 \\
\hline 8 & Tset & $\begin{array}{l}\text { Thermostat setting } \\
\text { Temperature }{ }^{\circ} \mathrm{C}\end{array}$ & $\begin{array}{c}\mathrm{Tload} \\
\text { Tload }+10\end{array}$ & 1 \\
\hline 9 & Qaux & $\begin{array}{l}\text { Maximum auxiliary } \\
\text { heating power }(\mathrm{kW})\end{array}$ & {$[1.2,4.5]$} & 0.1 \\
\hline
\end{tabular}

Table (2). System materials and their thermal properties

\begin{tabular}{|c|c|c|}
\hline No & Property & Values \\
\hline $1-$ & Fluid specific heat (kJ/kg.K) & 4.19 \\
\hline $2-$ & Intercept efficiency $(\mathrm{a} 0)$ & 0.58 \\
\hline $3-$ & $\begin{array}{l}1^{\text {st }} \text { order efficiency coefficient (a1) } \\
\left(\mathrm{kJ} / \mathrm{hr} \cdot \mathrm{m}^{2} \cdot \mathrm{K}\right)\end{array}$ & 12.96 \\
\hline 4- & $\begin{array}{l}2^{\text {nd }} \text { order efficiency coefficient (a2) } \\
\left(\mathrm{kJ} / \mathrm{hr} \cdot \mathrm{m}^{2} \cdot \mathrm{K}^{2}\right)\end{array}$ & 0.054 \\
\hline $5-$ & Tested flow rate per unit area & 77 \\
\hline $6-$ & $\begin{array}{l}\text { Fluid specific heat at test conditions } \\
\mathrm{kJ} / \mathrm{kg} . \mathrm{K}\end{array}$ & 4.190 \\
\hline 7- & 1st-order IAM coefficient (-) & 0.8 \\
\hline $8-$ & 2nd-order IAM coefficient (-) & 0.0 \\
\hline 9- & Capacitance of Collector (kJ/k) & 17 \\
\hline 10 & Tank heat loss coefficient (kJ/K.m2) & 1.725 \\
\hline
\end{tabular}

The prices required by the design tool for system components and electricity unit are given in Table 3. The components cost is taken from the SWH manufacturer at our records in the CSERS.



Figure (2). Flow chart of the SWH system design tool

Table (3). Solar system material and prices

\begin{tabular}{|l|l|l|}
\hline No & Item & Prices \\
\hline 1 & Collector & $103.28 \mathrm{~L} . \mathrm{D} / \mathrm{m}^{2}$ \\
\hline 2 & Storage Tank & $2.2 \mathrm{~L} . \mathrm{D} / \mathrm{Lit}$ \\
\hline 3 & Electricity price & $0.11 \mathrm{~L} . \mathrm{D} / \mathrm{kWh}$ \\
\hline
\end{tabular}

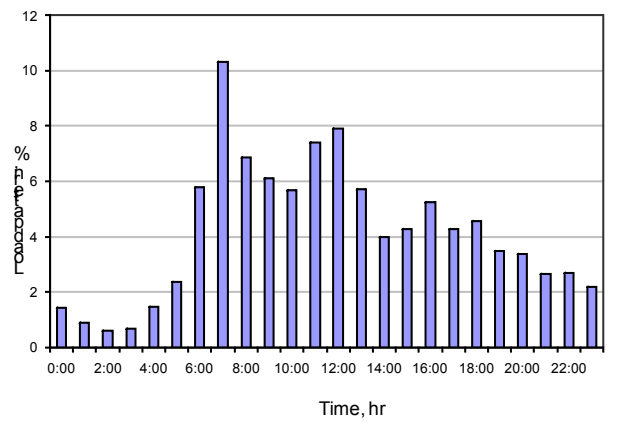

Figure (3). Typical hot water load pattern for Libyan families in Tripoli

\section{OPTIMUM SYSTEMS}

For four people family size

The design tool was implemented to find the 
optimum system design that can provide the household with 240 liters of daily hot water at a temperature of $45{ }^{\circ} \mathrm{C}$ for different solar fraction values (4 people family). The results of 85 simulation runs are shown in Figure 4 and the corresponding design parameters values of non-dominated solutions are given in Table 4. Figure 3 represents the trade-off curve between the cost of the system and the solar fraction of the system in which the grey circular points represent feasible solutions set (dominated solution), and the solid line and black circular points represent the Pareto optimal set (non-dominated solution). The feasible solution set is the set of all solutions that do not violate the constraints. Whereas, the Pareto optimal set is the non-dominated subset of the feasible set.
Table (4). Some of system design parameters (4 people family)

\begin{tabular}{|l|l|l|l|l|l|l|}
\hline GEN no & 144 & 999 & 194 & 995 & 980 & 385 \\
\hline COST & 357 & 431 & 471 & 529 & 618 & 725 \\
SF & 0.302 & 0.429 & 0.504 & 0.596 & 0.704 & 0.812 \\
Tuser $\left({ }^{\circ} \mathrm{C}\right)$ & 44.95 & 44.26 & 44.19 & 44.27 & 44.46 & 44.6 \\
Noc & 1 & 1 & 2 & 2 & 2 & 3 \\
AC $\left(\mathrm{m}^{2}\right)$ & 1.155 & 1.619 & 1 & 1.155 & 1.46 & 1.232 \\
BTA $(\mathrm{deg})$ & 31.1 & 32.7 & 39.9 & 33.8 & 34.4 & 32.7 \\
MP $(\mathrm{kg} / \mathrm{hr})$ & 47.42 & 30.56 & 41.67 & 39.36 & 34.28 & 40 \\
DTx $\left({ }^{\circ} \mathrm{C}\right)$ & 5 & 9.33 & 7.33 & 6.33 & 7.33 & 8.67 \\
DTn $\left({ }^{\circ} \mathrm{C}\right)$ & 1.4 & 2.6 & 2.2 & 1.2 & 1 & 1 \\
Vt $\left(\mathrm{m}^{3}\right)$ & 0.108 & 0.12 & 0.12 & 0.132 & 0.144 & 0.156 \\
Tset $\left({ }^{\circ} \mathrm{C}\right)$ & 47.9 & 45.3 & 45.3 & 45.3 & 45.3 & 45.3 \\
Qaux $(\mathrm{kW})$ & 2.7 & 3.75 & 4.7 & 4.49 & 4.7 & 5.1 \\
\hline
\end{tabular}



Figure (4). Trade-off between cost and solar fraction (4 people family)

\section{For six people family size}

In this case more than 95 points were considered for constructing Figure (5) of the Pareto optimal set of the optimum size of active solar water heating system. The expected system should provide 360 liters of hot water at $45^{\circ} \mathrm{C}$ per day. The obtained optimum tank volume is nearly 300 liters at a solar fraction of $90 \%$. This is less than the daily hot water withdrawn. The maximum required collector area was about $6.55 \mathrm{~m}^{2}$ which is a quite large area, but the area drops to $4.4 \mathrm{~m}^{2}$ and 235 liters of tank volume in case of $70 \%$ solar fraction. However, the system of $4.4 \mathrm{~m}^{2}$ collector area and 300 liters of tank volume is the commonly available system in the market. 
Table 5 Some of system design parameters (6 people family)

\begin{tabular}{|l|l|l|l|l|l|l|}
\hline \multicolumn{1}{|c|}{ GEN no } & \multicolumn{1}{|c|}{370} & \multicolumn{1}{|c|}{876} & \multicolumn{1}{c|}{997} & \multicolumn{1}{c|}{756} & \multicolumn{1}{|c|}{179} & \multicolumn{1}{|c|}{813} \\
\hline COST & 597 & 674 & 786 & 889 & 967 & 1128 \\
SF & 0.303 & 0.4 & 0.515 & 0.605 & 0.698 & 0.811 \\
Tuser $\left({ }^{\circ} \mathrm{C}\right)$ & 44.97 & 44.34 & 44.2 & 44.05 & 44.2 & 44.5 \\
Noc & 1 & 2 & 3 & 2 & 2 & 3 \\
AC $\left(\mathrm{m}^{2}\right)$ & 1.774 & 1.155 & 1 & 1.81 & 2.19 & 1.93 \\
BTA $(\mathrm{deg})$ & 30 & 31.64 & 30.00 & 34.94 & 33.29 & 43.16 \\
MP $(\mathrm{kg} / \mathrm{hr})$ & 60 & 100 & 100 & 100 & 100 & 100 \\
DTx $\left({ }^{\circ} \mathrm{C}\right)$ & 5.6774 & 9 & 6.7 & 5.7 & 5 & 7.7 \\
DTn $\left({ }^{\circ} \mathrm{C}\right)$ & 2.6 & 1.2 & 1 & 1 & 1 & 1 \\
Vt $\left(\mathrm{m}^{3}\right)$ & 0.188 & 0.198 & 0.2165 & 0.234 & 0.235 & 0.241 \\
Tset $\left({ }^{\circ} \mathrm{C}\right)$ & 45.3 & 45.3 & 45.3 & 45.3 & 45.3 & 45.3 \\
Qaux $(\mathrm{kW})$ & 1.8 & 4.3 & 4.2 & 2.5 & 2.3 & 4.3 \\
\hline
\end{tabular}

\section{For eight people family size}

The optimum design of active SWH system suitable for 8 people family size is sought. The tradeoff curve between the solar fraction and the system cost from 63 simulation runs is shown in Figure 6. The designed daily hot water withdrawal at $45^{\circ} \mathrm{C}$ is
460 litres. The optimum design of the system that can provide $90 \%$ of solar fraction was $7.86 \mathrm{~m}^{2}$ and 432 litres. Other design parameters values of the non-dominated solution of Pareto optimal set are listed in Table 6.

\section{CONCLUSIONS}

This paper seeks the optimum design of active solar water heaters that can be utilized in the residential sector of Libya and suitable for different family sizes. Genetic algorithm optimization procedure was adopted in this study for this purpose because of its ability to optimize multiple parameters simultaneously. This was then combined with the TRNSYS program for evaluating the thermal performance of the candidate solutions by the optimizer. Nine influential design parameters were considered for optimization in this study. Three family sizes were investigated for the optimal SWH system. The Pareto optimal set for the three cases is obtained and the values of design parameters are listed in tables.

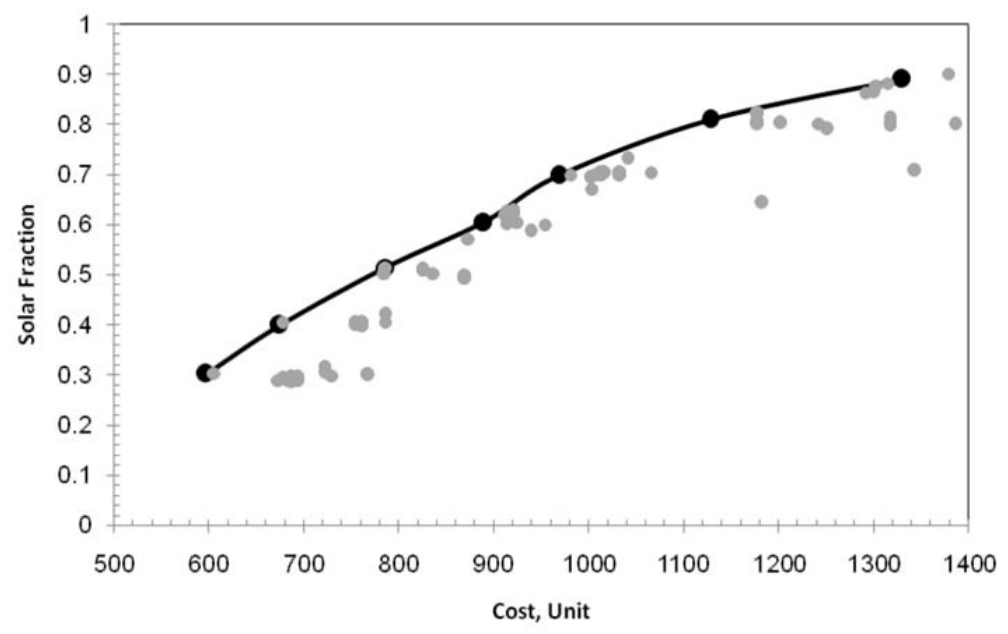

Figure (5). Trade-off between cost and solar fraction of 6 people family SWH system 


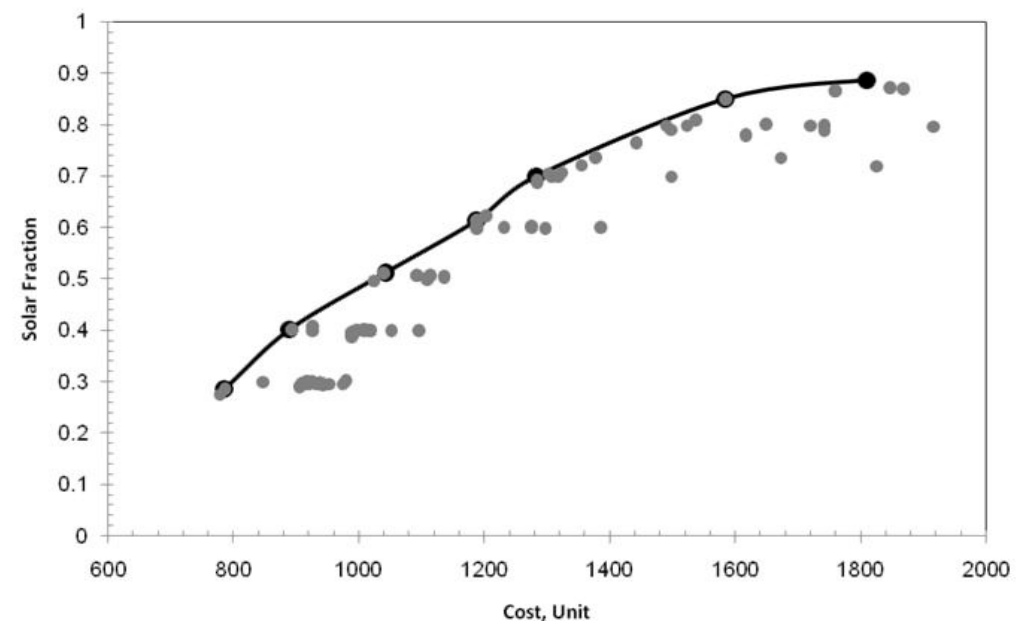

Figure (6). The trade-off between the cost and solar fraction of 8 people family SWH system

The study has proved that the design tool can be used effectively for sizing active SWH systems, and also for different climatic and operational conditions.

Table (6). Some of system design parameters (8 people family)

\begin{tabular}{|l|l|l|l|l|l|l|}
\hline \multicolumn{1}{|l|}{ GEN no } & 993 & 997 & 642 & 556 & 991 & 150 \\
\hline COST & 890 & 1042 & 1188 & 1284 & 1585 & 1811 \\
SF & 0.403 & 0.512 & 0.61 & 0.70 & 0.85 & 0.89 \\
Tuser $\left({ }^{\circ} \mathrm{C}\right)$ & 44.4 & 44.2 & 44.1 & 44.3 & 44.4 & 44.4 \\
Noc & 3 & 3 & 3 & 3 & 5 & 5 \\
AC (m $\left.{ }^{2}\right)$ & 1 & 1.32 & 1.62 & 1.93 & 1.57 & 1.572 \\
BTA (deg) & 32.75 & 36.7 & 34.4 & 32.7 & 36 & 36 \\
MP (kg/hr) & 100 & 100 & 111 & 100 & 100 & 100 \\
DTx ( $\left.{ }^{\circ} \mathrm{C}\right)$ & 7.7 & 5 & 5.7 & 5.3 & 5 & 6.3 \\
DTn ( $\left.{ }^{\circ} \mathrm{C}\right)$ & 1 & 1.6 & 1.2 & 1 & 1 & 1.2 \\
Vt (m3) & 0.264 & 0.288 & 0.312 & 0.312 & 0.352 & 0.432 \\
Tset ( $\left.{ }^{\circ} \mathrm{C}\right)$ & 45.3 & 45.3 & 45.3 & 45.3 & 45.3 & 45.3 \\
Qaux (kW) & 3.3 & 4.4 & 4.1 & 3.7 & 4.3 & 5.9 \\
\hline
\end{tabular}

\section{NOMENCLATURE}

$\begin{array}{ll}\text { Ac } & \text { Collector area } \mathrm{m}^{2} \\ \text { BTA } & \text { Collector slope }(\mathrm{deg}) \\ \text { DTx } & \text { Maximum differential temperature }\left({ }^{\circ} \mathrm{C}\right) \\ \text { DTn } & \text { Minimum differential temperature }\left({ }^{\circ} \mathrm{C}\right) \\ \text { Gen no } & \text { Generation number } \\ \text { MP } & \text { Pump maximum flow rate }(\mathrm{Kg} / \mathrm{hr}) \\ \text { Noc } & \text { Number of collectors } \\ \text { Paux } & \text { Auxiliary energy input to tank }(\mathrm{KJ} / \mathrm{hr}) \\ \text { Tset } & \text { Auxiliary heater setting temp }\left({ }^{\circ} \mathrm{C}\right) \\ \text { SF } & \text { Solar fraction } \\ \text { UA } & \text { Overall UA value for tank }\left(\mathrm{KJ} / \mathrm{hr}{ }^{\circ} \mathrm{C}\right) \\ \text { Vt } & \text { Tank volume (Lit) }\end{array}$

\section{REFERENCES}

[1]. Morrison, G. L. and J. E. Braun, "System modelling and operation characteristics of thermosyphon solar water heaters, Solar Energy", vol. 34, pp. 389-405, 1985.

[2]. Shariah, A. M., Douglas, C. Hittle and Lof, G.O.G, "Computer simulation and optimization of design parameters for thermosyphon solar water heater", in Proc. Joint solar Engineering Conference ASME, pp. 393-399, 1994. 
[3]. Shariah, A. and Shalabi, B., "Optimal design for a thermosyphon solar water heater", Renewable Energy, Vol. 11, No. 3 pp. 351-361, 1994.

[4]. Hasan A., "Thermosyphon solar water heaters: effect of storage tank volume and configuration on efficiency", Energy Conversion and Management, Vol. 38, No. 9, pp. 847-854, 1997.

[5]. Barley C. D,, and Winn C. B., "Optimal sizing of solar collector by the method of relative areas", Solar Energy, Vol. 21, pp. 279-289, 1978.

[6]. Michelson E., "Multivariate optimisation of a solar water heating system using SIMPLEX method", Solar Energy, Vol. 29, No. 2, pp. 89-99, 1982.

[7]. Pedersen P. V., "System design optimisation for large building integrated solar heating system for domestic hot water", Solar Energy, Vol. 50, No. 3, pp. 267-273, 1993.

[8]. Kulkarni G. N., Kedare S. B., and Bandyopadhyay S., "Determination of design space and optimisation of solar water heating systems", Solar Energy, Vol. 81, pp. 958-968, , 1993.

[9]. Gupta, C. L. and H. P. Garg, "System design in solar water heaters with natural circulation", Solar Energy, Vol. 12, pp. 163-182, 1968.

[10]. Norton B. and Probert, S. D., "Optimising the design of natural-circulation solar-energy water heaters", in Proc. Passive and Low Energy Architecture, pp. 587$596,1983$.

[11]. Malkin, M. P., Klein, S. A., Duffie, J. A., Copsey, A. B., "Design methods for thermosyphon solar domestic hot water systems", Journal of Solar Energy Engineering, Transactions of the ASME, Vol. 109, No. 2, pp. 150-155, 1987.
[12]. Shariah, A. M. and G. O. G. Löf, "The optimization of tank-volume-to-collector-area ratio for a thermosyphon solar water heater", Renewable Energy, Vol. 7, No. 3, pp. 289-300, 1996.

[13]. Kicsiny R., Farkas I., "Improved differential control for solar heating Systems", Solar Energy, Vol 86, No. 11, pp. 3489-3498, 2012

[14].Jason Ng, Cheng Hin., and Radu Zmeureanu., "Optimization of Residential Solar Combi-system for Minimum Life Cycle Energy and Cost", Proc. of eSim 2012: The Canadian Conference on Building Simulation, pp 29-107, 2012.

[15]. Krause M., Vajen K., Wiese F., Ackermann H., "Investigations on optimizing large solar thermal systems", Solar Energy, Vol. 73, No. 4, pp. 217-225, 2002.

[16]. Chang K. K, and Minardi A., "An optimisation formulation for solar heating systems", Solar Energy, Vol. 24, pp. 99-103, 1980.

[17]. Govind N. Kulkarni, Shireesh B. Kedare, Santanu Bandyopadhyay, "Determination of Design Space and Optimization of Solar Water Heating Systems", Solar Energy, Vol. 81, pp. 958-968, 2007.

[18]. Pereira M .C, Gordon J .M ., Rabl A ., and Zarmi Y., "Design and optimization of solar industrial hot water systems with storge", Solar Energy, Vol. 32, No. 1, pp. 121-133, 1984

[19]. Branemuehl M. J, Beckman W. A., "Economic evolution and optimization of solar heating systems", Solar Energy, Vol 23, pp. 1910, 1979,.

[20]. Abdunnabi M., "Optimum values of tank volume to collector area ratios of thermosyphon solar water heaters for Libyan families", Journal of Solar Energy and Sustainable Development (JSESD), Vol. 1, No. 1, pp. 25-31, 2012 